\title{
Exploring the desiccation tolerance of the invasive bivalve Corbicula fluminea (Müller 1774) at different temperatures
}

\author{
Simone Guareschi (iD $\cdot$ Paul J. Wood
}

Received: 21 November 2019/Accepted: 16 May 2020/Published online: 26 May 2020

(C) The Author(s) 2020

\begin{abstract}
Corbicula fluminea (Müller, 1774) (Mollusca, Corbiculidae) is among the most successful and widespread invaders of aquatic ecosystems worldwide. Given its wide geographical distribution and documented effects on aquatic ecosystems, there is considerable interest in quantifying its behaviour, propagation and control. We conducted a series of laboratory experiments to assess the effects of complete desiccation (aerial exposure at high relative humidity) on a UK population of $C$. fluminea for: (1) different environmental temperatures (6 scenarios: from cool winter droughts to summer heatwave thermal conditions); and (2) two size classes $(>1 \mathrm{~cm}$ and $\leq 1 \mathrm{~cm})$. A mortality rate of $100 \%$ was obtained for all experiments, except the lowest temperature scenario of $4{ }^{\circ} \mathrm{C}$. For both high-temperature scenarios $\left(25\right.$ and $\left.30{ }^{\circ} \mathrm{C}\right) 100 \%$ mortality was recorded after $48 \mathrm{~h}$, and an elevated mortality rate recorded after $24 \mathrm{~h}$. An extended period of desiccation of 5-6 days would be necessary to reach a mortality rate of $90 \%$ at $15{ }^{\circ} \mathrm{C}$ and 3.5 days at $20{ }^{\circ} \mathrm{C}$. Statistical analysis demonstrated a significant effect of
\end{abstract}

Electronic supplementary material The online version of this article (https://doi.org/10.1007/s10530-020-02291-9) contains supplementary material, which is available to authorized users.

S. Guareschi $(\bowtie) \cdot$ P. J. Wood

Geography and Environment, Loughborough University, Loughborough, Leicestershire LE11 3TU, England, UK

e-mail: S.Guareschi@lboro.ac.uk temperature on mortality, but both size classes displayed similar responses to desiccation. The greatest difference in mortality was recorded between the highest and lowest experimental temperatures. $C$. fluminea was particularly tolerant to desiccation when low temperature and high humidity conditions coincided, suggesting it could potentially spread to regions beyond its current eco-geographical range. The results will be of direct interest for regulatory authorities considering desiccation (and water level management) as a means of managing and preventing the further spread of this species.

Keywords Biological invasions - Physiological trait · Alien species · Asian clams · Dewatering · Droughts

\section{Introduction}

Biological invasions represent some of the most important threats to biodiversity globally and understanding their effects, consequences and potential ways of managing them represent major challenges for pure and applied science (e.g., Simberloff et al. 2013; Havel et al. 2015; Bellard et al. 2016). Freshwater ecosystems have been heavily invaded (Strayer, 2010) and among invertebrate invaders, molluscs and 
crustaceans are the most frequently groups recorded (Karatayev et al. 2009; Fenoglio et al. 2016).

Corbicula fluminea (Müller, 1774) is a freshwater bivalve (Mollusca, Corbiculidae), commonly called "Asian Clam", originating from Southeast Asia (Gomes et al. 2016). It has a yellow-brown globular shell, usually $<30 \mathrm{~mm}$ width (Zieritz, 2016), and is both a filter- and pedal-feeder in benthic ecosystems (Hakenkamp et al. 2001). It is considered among the most widespread and hyper-successful invaders in aquatic ecosystems globally due to its highly effective traits including: rapid growth, high fecundity with both sexual and asexual reproduction strategies, high dispersal capacity and its strong association with human activities including aquaculture (Sousa et al. 2008a; Jou and Liao 2006; Ilarri et al. 2011; Verbrugge et al. 2012; Sousa et al. 2014; Laverty et al. 2015).

C. fluminea has been present in Europe (Portugal and France) since at least the early 1980s (Mouthon, 1981, see Sousa et al. 2008a for a complete invasion history). Its invaded geographic area appears to be expanding within regions it has already successfully colonised (e.g., Spain-Zamora-Marín et al. 2018), encompassing wide climatic conditions from semiarid northern Africa (Morocco, Clavero et al. 2012) to northern Europe (North Russia-Bespalaya et al. 2018), with further expansions predicted due to climate change (Gama et al. 2017).

It is listed among the "worst invaders" within Europe (Nentwig et al. 2018), considered one of the five most important freshwater suspension feeding invaders (Karatayev et al. 2007) and has been identified as a high-risk aquatic invasive species in Great Britain (Gallardo and Aldridge 2013). The first record of $C$. fluminea in England was in 1998 (Baker et al. 1999) and it is currently recorded and abundant in several UK rivers (including the River Thames and numerous tributaries, Elliott and zu Ermgassen 2008). Moreover, the extensive navigation network of England allows inter-basin transfers of water, which may facilitate the expansion of its range (Gallardo and Aldridge 2018).

As a major freshwater bio-fouler (Nakano and Strayer 2014) it can form large agglomerations of live individuals and the dead shells may form extensive benthic deposits on riverbeds and in artificial waterbodies (e.g. drainage channel infrastructure). Biofouling and impairment of water-dependent industries in the USA (e.g., Johnson et al. 1986) and within irrigation systems in Europe have been reported (e.g. Rosa et al. 2011).

In both natural and regulated rivers, Corbicula fluminea typically becomes one of most important components of benthic fauna in terms of abundance and biomass once established (e.g. Sousa et al. 2008b). This can result in major changes to other faunal and floral populations including submerged macrophytes, phytoplankton, zooplankton and for biogeochemical cycling (see Sousa et al. 2008a for details). In addition, negative effects on indigenous freshwater bivalve populations have been recently reported on the Iberian Peninsula (Ferreira-Rodríguez et al. 2018) and UK (Lopes-Lima et al. 2017).

Due to its widespread distribution and high densities across many aquatic habitats, from lotic systems to lakes and estuarine zones (Rosa et al. 2011), there is considerable interest in the behaviour, propagation, economic impacts management and control of $C$. fluminea (Doherty and Cherry 1988; Ortmann and Grieshaber 2003; Sousa et al. 2009; Rosa et al. 2011; Crespo et al. 2015; Coughlan et al. 2019). Eradication of $C$. fluminea would appear unrealistic in most circumstances, whereas control activities may prove more promising (Sousa et al. 2014). Aquatic disinfectants, including bleach and salt solutions have been tested as control measures in aquaria, and laboratory methods developed exposing individuals directly to hot steam or contact with dry ice have recently been described (Coughlan et al. 2018, 2019). However, control measures for invasive aquatic organisms require maximum efficacy whilst minimising wider environmental and ecological damage (e.g. impacts on no-target organisms or downstream river sections) when applied in the field. Among abiotic variables, thermal tolerances appear to be a primary factor influencing the fitness and potential spread of $C$. fluminea populations (Weitere et al. 2009; Müller and Baur 2011). For instance, Werner and Rothhaupt (2008) reported that winter water temperatures $<2{ }^{\circ} \mathrm{C}$ for several weeks limited survival rates of $C$. fluminea in Lake Constance (Central Europe) while McDowell et al. (2014) indicated that the minimum air temperature may influence its distribution within the USA.

In the temperate zone, elevated water and air temperature, and river channel drying (desiccation) is typically associated with summer drought and 
heatwaves, although flow cessation and channel drying may occur throughout the year (e.g. Folland et al. 2015; Tolonen et al. 2019). Desiccation resistance has been shown to affect the distribution of many aquatic invertebrate taxa (e.g. Ricciardi et al. 1995; Pallarés et al. 2016). Given predicted climate change and drought intensification scenarios (Prudhomme et al. 2014) a greater understanding of the response and adaptably of aquatic invaders like $C$. fluminea may aid in forecasting how its distribution may change or help target control measures. For molluscs, the effect of bivalve size on stress tolerance and mortality rates has been reported to be highly variable and potentially influenced by thermal regimes. Smaller clams have been hypothesised to be more susceptible to thermal shock than larger individuals in some settings (Werner and Rothhaupt 2008; Coughlan et al. 2018) while Byrne et al. (1988) reported increased size had a negative effect on mortality at temperatures of $25^{\circ} \mathrm{C}$ and $35{ }^{\circ} \mathrm{C}$. As a result, there is an urgent need to improve our knowledge regarding desiccation tolerance and drought resistance of $C$. fluminea to inform the development of biosecurity tools for controlling and preventing its further spread; especially in temperate regions where populations are expanding rapidly (Elliott and zu Ermgassen 2008).

To address this research gap and provide thermal and desiccation tolerance information, we conducted a series of laboratory experiments to assess the effects of desiccation (aerial exposure) on a UK population of $C$. fluminea for: (1) different environmental temperatures $\left(4,11,15,20,25,30^{\circ} \mathrm{C}\right)$ and (2) two size classes. Experimentally testing the effects of exposure to different air temperature regimes will provide a better understanding of the desiccation tolerance of $C$. fluminea under varying climatic conditions (e.g. winter drought through to summer heatwave thermal conditions). Examination of different size classes will allow better characterization of which acts as the most effective propagule in response to drought/desiccation conditions. We hypothesized that increasing air temperature reduces $C$. fluminea survivorship, and that mortality rates are influenced by body size.

\section{Methods}

Study area and field work

Specimens of C. fluminea (Bivalvia, Corbiculidae) were collected from Hermitage Brook (WGS84 $52^{\circ} 46^{\prime} 02^{\prime \prime} \mathrm{N}$; $01^{\circ} 11^{\prime} 27^{\prime \prime} \mathrm{W}$, altitude: $41 \mathrm{~m}$ a.s.1.) a $2.5 \mathrm{~km}$ watercourse that links the Grand Union Canal Leicester Navigation with the River Soar (Leicestershire, UK). The waterway supported an abundant population of $C$. fluminea and can be considered a representative section of the large waterway network that links anthropogenic and natural waterbodies in lowland England.

Sampling was undertaken during late spring-early summer 2019 (May- early July) when flow was close to baseflow conditions and as a result, physicochemical variables were relatively stable over the study period: temperature $17.5 \pm 1.8^{\circ} \mathrm{C}$ (mean \pm SD), conductivity $616 \pm 89 \mu \mathrm{S} / \mathrm{cm}$ and $\mathrm{pH}$ $7.6 \pm 0.06$.

Based on the maximum shell length, $C$. fluminea individuals were separated in two size classes in the field using a sieve: (1) "adults" (>1 cm) and (2) "juveniles" ( $\leq 1 \mathrm{~cm})$. Size is typically a good proxy of age and development stage in bivalves; for instance, Caffrey et al. (2011) referred to the one-year old cohort when shell height was less that $11 \mathrm{~mm}$ and Sousa et al. (2008a) classified C. fluminea individuals of $10 \mathrm{~mm}$ or greater as adults.

Laboratory experiments

Specimens were kept in the laboratory for $24 \mathrm{~h}$ $\left(20 \pm 1^{\circ} \mathrm{C}\right)$ in aerated tanks containing water from the collection site to confirm survivorship and normal feeding behaviour before starting each experiment. Pilot experiments were conducted to test the experimental procedure in order to avoid confounding effects due to starvation (maximum length of each treatment was set to 10 days). Each experiment was conducted at a constant temperature in an environmental chamber (TAS, Series 3, England) with relative humidity (RH) maintained at around $80 \%$ $(81 \pm 4 \%$, mean $\pm \mathrm{SD})$. The constant high $\mathrm{RH}$ in all the desiccation treatments allowed us to focus on the effects of temperature and size of individuals. A total of six temperature scenarios were tested for each size class $\left(4,11,15,20,25,30^{\circ} \mathrm{C}\right)$. The coldest scenario 
represents a winter drought scenario, typical of average air temperatures during January in the UK (period 1981-2010, https://www.metoffice.gov.uk/ climate/uk/summaries/actualmonthly). The higher temperature scenarios $\left(25\right.$ and $30{ }^{\circ} \mathrm{C}$ ) were both higher than the mean daily maximum temperature during summer (July and August) for the period 1981-2010 and were used as analogies for periods of sustained high temperature under potential future climate change conditions. The remaining thermal treatments $\left(11,15,20{ }^{\circ} \mathrm{C}\right)$ reflect conditions typical of spring to summer in the UK.

Following the acclimation period, for each temperature scenario, 100 individuals of each size class were dried on blotting paper and placed individually into clean $50 \mathrm{~mL}$ open plastic thermal resistant vials so that individual $C$. fluminea were not in contact with each other. A further 20 individuals per size-class were placed in a $15 \mathrm{~L}$ aquarium at the same experimental air temperature and used as a control not subjected to desiccation stress. Overall, the experiments included 1200 individuals (100 individuals $* 6$ scenarios $* 2$ sizes $=1200$ ind.) and 240 individuals were used for controls. For each scenario, every $24 \mathrm{~h}$, ten individuals were selected at random from each size-class (adults and juveniles) and immersed in water to determine the number of individuals alive (see SM1 for a scheme). Mortality was deemed to have occurred if individuals did not commence filtering or move within $2 \mathrm{~h}$. In addition, mortality was considered to have occurred if shells were found open before immersion in water. For shells that were closed, mortality was confirmed if: i) there was a pool of fluid around the shell (due to the emptying of the mantle cavity water store) or ii) the smell of decomposing body tissue.

\section{Statistical analysis}

To assess the effect of "size" (adults and juveniles), "temperature" and their interaction, linear modelling (aov function in Stats package) was undertaken using mortality rate as the dependant variable. Potential differences in mortality rates among temperature scenarios were tested by applying the post hoc Dunn test (Dunn 1964) appropriate for comparing unequal sample sizes (Zar 2010). This test performs multiple comparisons following a Kruskal-Wallis test providing both z-test-statistics and the $p$ value for each pairwise comparison. Model residuals were graphically checked for normality (confirmed by Shapiro-Wilk test, after logit transformation: $\log (Y /$ $[1-Y])$ ) and homoscedasticity assumptions (Zuur et al. 2009).

In addition, two different thermal tolerance indicators were calculated: lethal temperature (LT) and lethal time (lt) for two different mortality scenarios (50\% and 90\%) using a generalised linear model procedure (GLM: Crawley 1993). For these models the response variable only had two states (alive or dead) and a binomial distribution (quasibinomial when overdispersion was detected) was applied using the function dose.p in the MASS package (Venables and Ripley, 2002). The LT50 (defined as lethal temperature to reach $50 \%$ mortality at a specific time) and LT90 were tested for three fixed time scenarios (after 2, 5 and 7 days) and for both size classes to obtain a detailed comparison of trends.

Lethal times (1t50 and 1t90) were calculated using the GLM approach outlined above but using time ("day") as an independent variable. The 1t50 and 1t90 represent the time (number of days) required to reach a mortality rate of $50 \%$ and $90 \%$ respectively and were calculated for each temperature scenarios. All statistical analyses and graphical presentations were undertaken within R v. 3.6.2 (R Core Team 2018).

\section{Results}

Temperature and size class

For all scenarios tested (6 temperatures and 2 size classes), a mortality rate of $100 \%$ was obtained except for $4{ }^{\circ} \mathrm{C}(50 \%$ and $80 \%$ mortality for adults and juveniles respectively). The quickest response in mortality was obtained for the high-temperature scenarios (25 and $30{ }^{\circ} \mathrm{C}$, Fig. 1-2) with $100 \%$ mortality recorded after $48 \mathrm{~h}$ and elevated mortality rates recorded after $24 \mathrm{~h}$ (minimum values of $40-50 \%$ at $25^{\circ} \mathrm{C}$ ). In contrast, survivorship observed for the control groups kept in water at the same temperature averaged $90 \%$ at the end of each temperature treatment $(\min =70 \% ; \max =100 \%)$, with lowest survivorship $(70-80 \%)$ recorded at the end of the $30{ }^{\circ} \mathrm{C}$ air-temperature control treatment.

Analysis demonstrated a significant effect of air temperature $\left(\mathrm{F}_{(1,62)}=19.42, p<0.001\right)$, but no difference in mortality rates between the two size classes 


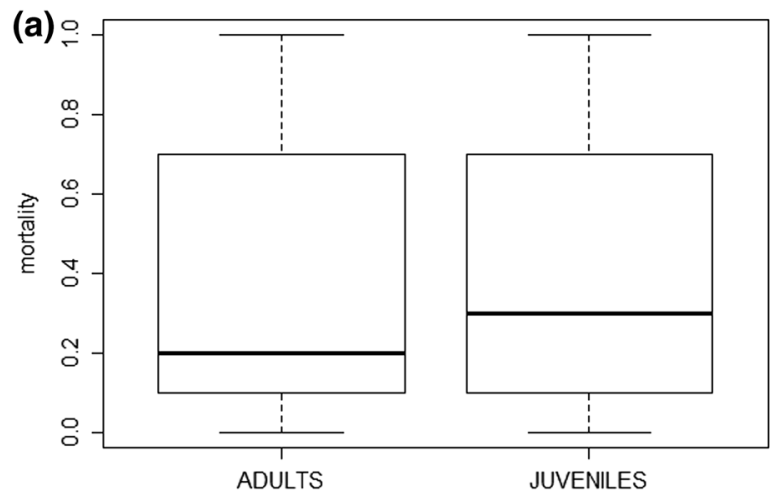

(c)

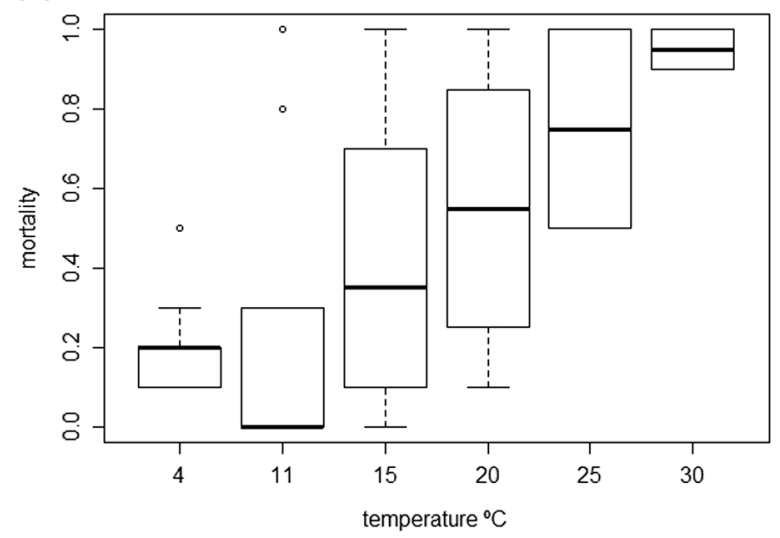

Fig. 1 Boxplots of Corbicula fluminea desiccation responses (percentage mortality) at different temperatures and sizeclasses. a comparison between adults and juvenile responses, b response for different temperature scenarios (see colour in Fig. 3); c Adult response for different temperature scenarios;

was observed ( $p>0.05$ and see Figs. 1, 2 and 3). In addition, the interaction between size classes and temperature (size class: temperature) was not statistically significant $(p>0.05)$.

Given that size class was not significantly different, pairwise analysis among temperature treatments were examined using the whole dataset $(n=66)$. Dunn's test indicated the largest differences in mortality were obtained for the extreme high $\left(25-30^{\circ} \mathrm{C}\right)$ and low $\left(4-11^{\circ} \mathrm{C}\right)$ temperature scenarios (Table 1$)$.

Lethal temperature and lethal time values

The response of $C$. fluminea during desiccation experiments for the three different time steps considered (day 2-5-7) and for both size classes are shown in

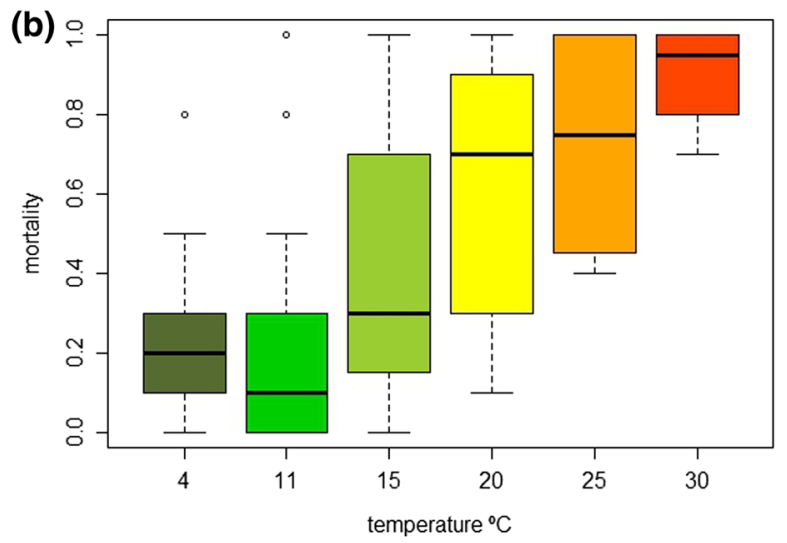

(d)

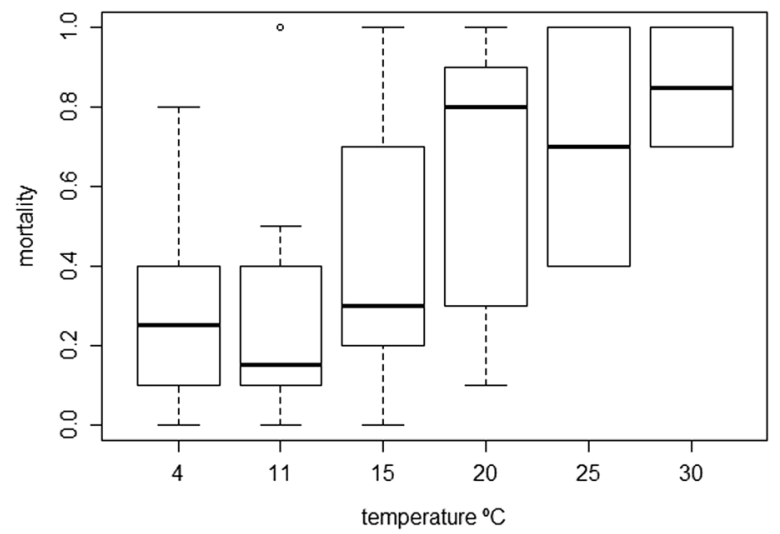

d Juvenile response for different temperature scenarios. The median is denoted by the bold horizontal line, the box delimits the interquartile range, and the whisker lines extend to the observed maxima and minima

Fig. 3. The lethal temperature (LT50 and LT90) and lethal time (1t50 and 1t90) values are presented in Table 2 and Table 3 respectively. Lethal temperatures (LT, Table 2) decreased over time in all instances (from day 2 to day 7) and the responses were comparable for both size classes (see also Fig. 1 and Fig. 3).

The LT50 was reached after two days at a temperature just below $20{ }^{\circ} \mathrm{C}\left(19.1-19.2{ }^{\circ} \mathrm{C}\right)$, while the LT90 was around $27{ }^{\circ} \mathrm{C}$, but in both instances displaying the largest standard errors. After 5 days LT values decreased to $13{ }^{\circ} \mathrm{C}$ and between 16 and $18{ }^{\circ} \mathrm{C}$ for LT50 and LT90 respectively for both size classes. The results were more heterogeneous after 7 days of desiccation exposure with temperatures that ranged 


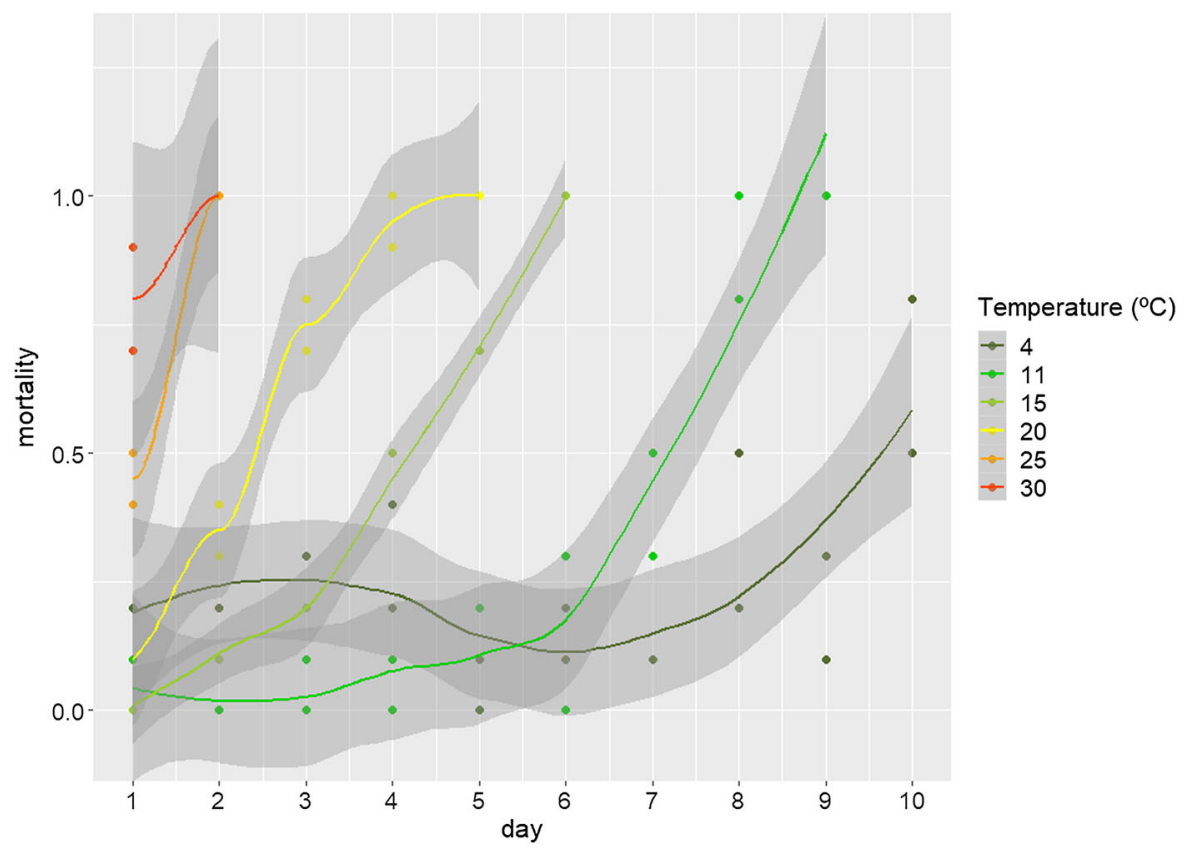

Fig. 2 Corbicula fluminea desiccation responses (percentage mortality on y-axis) for different temperature scenarios from day 1 to day 10. Loess curves with standard errors (dark grey)

between $9{ }^{\circ} \mathrm{C}$ and $11{ }^{\circ} \mathrm{C}$ for LT50 and $14-15{ }^{\circ} \mathrm{C}$ for LT90 (see Table 2).

Lethal time results largely confirmed the LT outputs for each temperature scenario tested (Table 3) and demonstrated that at $25{ }^{\circ} \mathrm{C}$ and $30{ }^{\circ} \mathrm{C}$ the 1 t 50 and lt90 was reached after 1 day $(24 \mathrm{~h})$, while periods of about 1 week ( 7 and 8.5 days) were required at $11{ }^{\circ} \mathrm{C}$ for 1 t50 and 1 t90 respectively. Intermediate values were obtained for $15{ }^{\circ} \mathrm{C}$ and $20{ }^{\circ} \mathrm{C}$ treatments. At $4{ }^{\circ} \mathrm{C}$ lethal times increased to around 10 days for $1 \mathrm{t} 50$ (see Table 3 for details).

\section{Discussion}

The present study provides new knowledge regarding the desiccation resistance of the highly successful invasive species $C$. fluminea. As far as we know, this represents the first experiments addressing desiccation tolerances of $C$. fluminea over a wide range of temperatures (simulations from winter through to summer drought and future climate change conditions) for a UK population. The potential desiccation tolerance of the species was noted by Baker et al. (1999) when first recorded in the UK (Norfolk) as a are displayed. Light grey space outside the range $0-1$ on the $\mathrm{y}$-axis is displayed to allow interpretation. Reduced number of points at $15^{\circ} \mathrm{C}$ is due to overlapping

single Corbicula specimen was found to be alive ten days after collection within the sample net, although no further abiotic information was provided regarding the conditions it was found in.

We found evidence to support our first hypothesis, that different temperatures had a significant effect on mortality rates. The greatest differences were recorded between the lowest and highest temperature scenarios: at $30{ }^{\circ} \mathrm{C} 100 \%$ mortality was recorded after two days $(48 \mathrm{~h})$ while at $4{ }^{\circ} \mathrm{C}$ some specimens survived until the end of the experimental period (ten days).

Non-native bivalves from the genus Dreissena ( $D$. polymorpha and D. bugensis) introduced in Canada survived emersion for up to 10 days at $10{ }^{\circ} \mathrm{C}(95 \%$ relative air humidity) and the authors suggested that individuals may also survive transport overland (Ricciardi et al. 1995). Similarly, our results for $C$. fluminea at $11{ }^{\circ} \mathrm{C}$ indicated survivorship after 1 week of desiccation ( 1 t50 $=7.3$ days). Lower temperatures (e.g., 4 and $11{ }^{\circ} \mathrm{C}$ with high relative humidity around $80 \%$ ) appear to favour desiccation tolerance of invasive bivalves like $C$. fluminea. These findings highlight the importance of considering different airtemperature scenarios on the survival capacity of organisms subject to drought and desiccation stresses. 

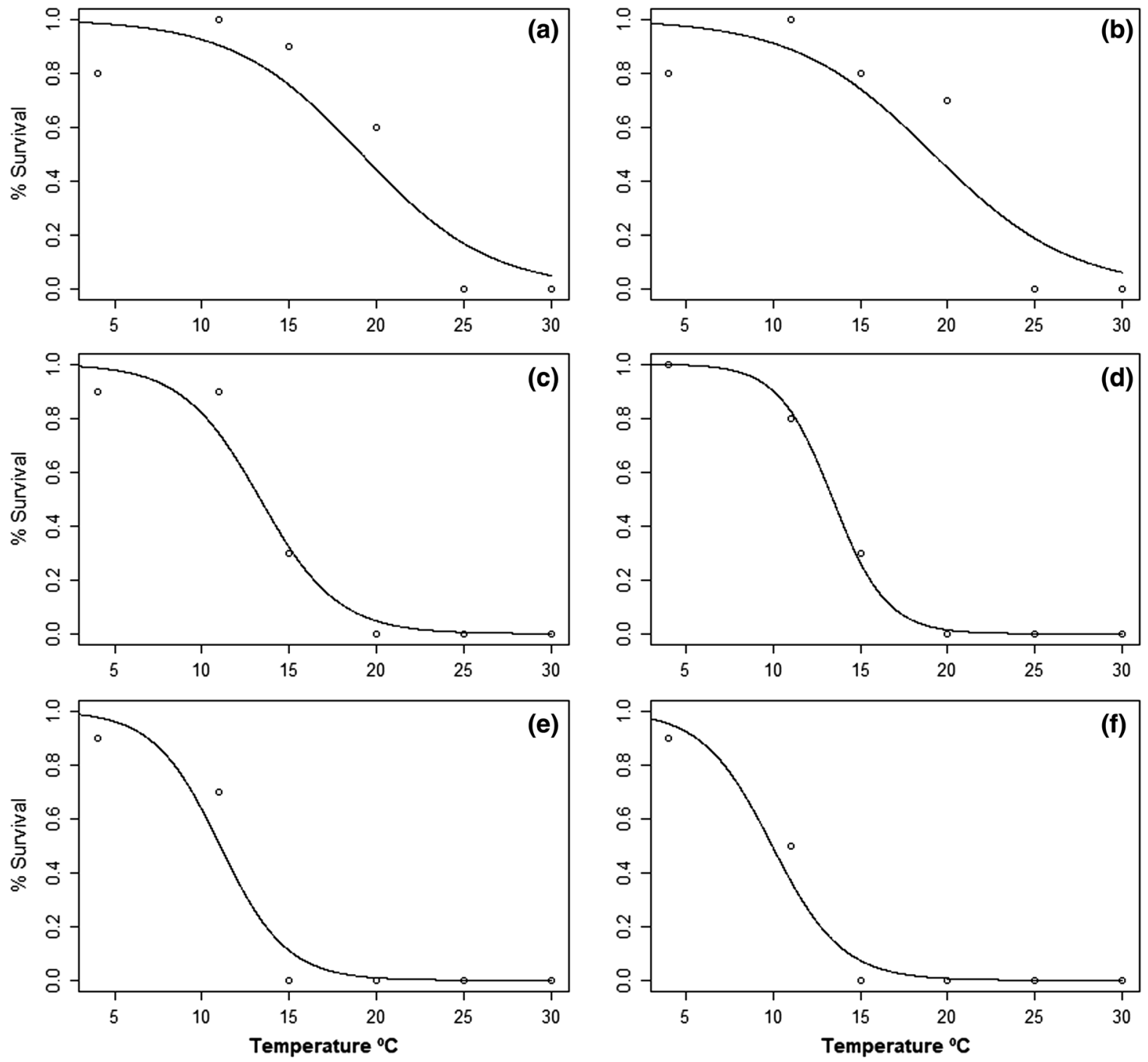

Fig. 3 Response of $C$. fluminea to desiccation at different temperature scenarios (percentage survival on the y-axis) for three different time period: day $2(\mathbf{a}, \mathbf{b})$, day $5(\mathbf{c}, \mathbf{d})$ and day 7 (e, f). Adult responses are displayed in the left column (letters $\mathbf{a}, \mathbf{c}$,

e) while juveniles are displayed on the right $(\mathbf{b}, \mathbf{d}, \mathbf{f})$. Data were fitted (survival curves) to a binomial GLM from which LT values were obtained

Table 1 Dunn test pairwise comparison of mortality values for different temperature scenarios. $Z$ test-statistics are provided

$* p<0.05: * * p<0.01$

\begin{tabular}{|c|c|c|c|c|c|c|}
\hline Temp ${ }^{\circ} \mathrm{C}$ & 4 & 11 & 15 & 20 & 25 & 30 \\
\hline 4 & & -0.62 & 0.93 & $1.97 *$ & $2.31 *$ & $2.78 * *$ \\
\hline 11 & & & -1.44 & $-2.41 *$ & $-2.64 * *$ & $-3.11 * *$ \\
\hline 15 & & & & -1.03 & -1.60 & $-2.05^{*}$ \\
\hline 20 & & & & & -0.79 & -1.22 \\
\hline 25 & & & & & & -0.36 \\
\hline
\end{tabular}


Table 2 Lethal Temperature (LT) for the 50\% (LT50) and $90 \%$ (LT90) for C. fluminea size-classes and duration times (2-5-7 days)

\begin{tabular}{lrlll}
\hline Tolerance indicator & Dose & SE & Time (day) & Size \\
\hline LT50 & 19.14 & 3.58 & 2 & Adults \\
LT90 & 27.20 & 6.35 & 2 & Adults \\
LT50 & 19.16 & 3.37 & 2 & Juveniles \\
LT90 & 27.87 & 6.14 & 2 & Juveniles \\
LT50 & 13.33 & 1.02 & 5 & Adults \\
LT90 & 18.22 & 1.68 & 5 & Adults \\
LT50 & 13.40 & 0.22 & 5 & Juveniles \\
LT90 & 16.80 & 0.36 & 5 & Juveniles \\
LT50 & 11.03 & 1.16 & 7 & Adults \\
LT90 & 15.20 & 1.70 & 7 & Adults \\
LT50 & 9.93 & 0.82 & 7 & Juveniles \\
LT90 & 14.31 & 1.09 & 7 & Juveniles \\
\hline
\end{tabular}

Dose (temperature in ${ }^{\circ} \mathrm{C}$ ) and Standard error (SE) are provided

Table 3 Lethal time (1t50 and 1t90) as number of days for $C$. fluminea during desiccation experiments

\begin{tabular}{llll}
\hline Tolerance indicator & Dose (no. days) & SE & Temp $\left({ }^{\circ} \mathrm{C}\right)$ \\
\hline lt50 & 0.90 & - & 30 \\
lt90 & 1.00 & 0.05 & 30 \\
lt50 & 1.00 & 0.03 & 25 \\
lt90 & 1.09 & - & 25 \\
lt50 & 2.29 & 0.16 & 20 \\
lt90 & 3.52 & 0.28 & 20 \\
lt50 & 4.02 & 0.18 & 15 \\
lt90 & 5.63 & 0.31 & 15 \\
lt50 & 7.31 & 0.23 & 11 \\
lt90 & 8.47 & 0.36 & 11 \\
lt50 & 10.44 & 3.08 & 4 \\
lt90 & 21.70 & 9.57 & 4
\end{tabular}

Analysis have been run with adult size data except for the $4{ }^{\circ} \mathrm{C}$ scenario because adults' mortality was never $>50 \%$ along the treatment $(\max =50 \%)$. Dose (number of days) and Standard error (SE) are provided. Symbol "_" = algorithm did not properly converge

Given the predicted increase in drought frequency and intensity in the UK (Rahiz and New 2013), these results have potential implications for the spread, management and control of invasive bivalves. The results highlight that the persistence and distribution models of invasive species within freshwater ecosystems should consider species desiccation tolerances. Even intermittent streams (systems with periodic drought and drying periods) rarely subject to invasion by aquatic taxa in most instances (Chiu et al. 2017) could experience limited invasion of $C$. fluminea if low temperatures and high humidity coincided (e.g. high latitude or high altitude site), although further field and laboratory research is required. The ability to rapidly disperse and establish populations in new geographic areas illustrates the success of this invasive species (e.g. Crespo et al. 2015). Our result suggests further expansions of the geographical range of $C$. fluminea is possible, covering a wider range of waterbodies and latitudes within its thermal tolerances. However, harsh winter conditions (spanning several weeks) may limit its survival and dispersal capacity (Werner and Rothhaupt 2008).

Median desiccation tolerance times for $C$. fluminea individuals from an outflow of Lake Benbrook (Texas, USA) at $35{ }^{\circ} \mathrm{C}$ (with a mean humidity of $75 \%$ ) of $24 \mathrm{~h}$ were obtained by Byrne et al. (1988) and are comparable to this study (despite specimens being placed on a desiccator plate rather than in individual vials). Greater differences might be anticipated for $25{ }^{\circ} \mathrm{C}$ and $15^{\circ} \mathrm{C}$ scenarios, with north American populations displaying 1 t50 values greater than those recorded in the present study (78 and $305 \mathrm{~h}$ compared to $24 \mathrm{~h}$ and $96 \mathrm{~h}$ ). These differences probably reflect the natural climatology of the two areas: Texas (USA) classified as humid subtropical (Köppen-Geiger classification $C f a$; Peel et al. 2007) while Leicestershire (England) is considered oceanic $(C f b)$ with greater differences between summer temperatures. Differences in the responses of $C$. fluminea inhabiting different climatological regions may reflect trait plasticity and the ability of individuals to survive desiccation stresses more effectively in subtropical climates. This may also reflect the longer time that $C$. fluminea has inhabited freshwater bodies in Southwest USA compared to the UK. The first USA records date back to the 1920s (Sousa et al. 2008a) and Texas was colonised and invaded during the 1960s (Howells, 1992); compared to the first records at the end of the $90 \mathrm{~s}$ in the UK. In addition, the presence of different invasive lineages in North America and Central Europe has been proposed (Gomes et al. 2016) and may account for differences in desiccation tolerances between populations. 
Interestingly, Collas et al. (2014) examined the effects of desiccation on $C$. fluminea collected under similar climatological conditions (the Netherlands, Central Europe, $C f b$ climate) and reported a 1 t50 (lethal time) of around $200 \mathrm{~h}$ at a fixed temperature of $20{ }^{\circ} \mathrm{C}$ (with average $\mathrm{RH}$ of $68 \%$ ). This is much longer than the 2.29 days $(55 \mathrm{~h})$ recorded in the current study and probably reflects some differences in experimental design, humidity values, acclimation periods and frequency in individual checks.

High humidity has been identified as a key factor influencing the behaviour, spread and drought tolerance of other molluscs (e.g. Lottia gigantea Miller et al. 2009), other invasive faunal species in desiccation tolerance experiments (Procambarus virginalis Guo et al. 2019) and the introduced marine alga, Codium fragile ssp. tomentosoides (Schaffelke and Deane 2005). Moreover, the importance of residual humidity between substrate interstitial pores has been recognised for some invasive mussels (e.g., Montalto and Ezcurra de Drago, 2003); but this may not be the case for C. Aluminea, as it does not typically form clusters of individuals. Similarly, moist substrates significantly increased the survivorship of another hyper-successful aquatic invader ( $D$. polymorpha) when exposed to the atmosphere (Paukstis et al. 1999). Our findings underline the need for caution when generalizing the effects or exposure/desiccation of species without comprehensive information regarding other abiotic factors (e.g., substrate composition and moisture) and specific geographic context. In addition, Crespo et al. (2015) also stressed the high ecophenotypic plasticity of $C$. fluminea and that it may not be possible to generalise some patterns or trends globally.

We did not find evidence to support our second hypothesis, that body size influenced the desiccation tolerance of $C$. fluminea. No significant differences in mortality were recorded between adults and juveniles, with both displaying similar median lethal temperatures and response (Table 2, Fig. 1 and 3). The absence of a specific effect of size on desiccation tolerance contrasts with some patterns reported for $C$. fluminea in other studies (see Byrne et al. 1988 in USA; Werner and Rothhaupt 2008 in Central Europe). Variable desiccation tolerances in relation to size have also been reported for D. polymorpha, with larger individuals being reported to be more resistant to aerial exposure than smaller individuals (Ricciardi et al. 1995; Paukstis et al. 1999), while Tucker et al. (1997) indicated that smaller zebra mussels had an advantage in some situations (e.g. when individuals settled in substrate pore spaces). However, other invasive bivalves such as Limnoperna fortunei (Dunker, 1857) (Bivalvia, Mytilidae) displayed increased desiccation tolerance, with the size of individuals in laboratory trials (Montalto and Ezcurra de Drago 2003).

It should be noted that in the current desiccation experiments the individuals were unable to move vertically and had no opportunity to seek refuge (burrowing) within the substrate. However, field observations indicate that $C$. fluminea individuals typically live just beneath the surface of sandy substrates, exposing part of the shell (Byrne et al. 1988) and only burrow to shallow depths (McMahon and Bogan 2001). Future experiments examining this behaviour and how it may influence desiccation tolerance as well as different body size/ontogeny classes would be of considerable value to advance our knowledge on this highly successful invasive species.

Devising safe and effective measures to control or eradicate bio-fouling organisms such as Asian clams represents a challenge for applied ecologists and environmental managers. For instance, McDowell et al. (2017) observed that over $99 \%$ of Corbicula were eliminated by immersion in water at $40{ }^{\circ} \mathrm{C}$ for $90 \mathrm{~s}$. Although the ability to achieve this under field conditions is unrealistic. Oxygen depletion and impermeable benthic barriers have produced promising results in the control of $C$. fluminea populations in Lake Tahoe (USA-Wittmann et al. 2012) and pelleted dry ice has been successfully utilised in Ireland on both submerged and emerged clams in laboratory trials (Coughlan et al. 2018). Dewatering and desiccation events have been proposed as potential alternatives to chemical control measures (especially given that no chemical products or impermeable infrastructure is required) in some situations for $D$. polymorpha (Paukstis et al. 1999). For instance, it has been suggested that aerial exposure (at temperatures $>20^{\circ} \mathrm{C}$ ) may be an effective control of zebra mussels in highly regulated waterways where water levels can be reduced for more than $24 \mathrm{~h}$ (Paukstis et al. 1999). In the current study, periods of $24 \mathrm{~h}$ with sustained air temperatures of around 25 and $30{ }^{\circ} \mathrm{C}$ eliminated $90 \%$ of individuals and has the potential to be used to control the spread of $C$. fluminea. However, 
more realistically, an extended period of at least 5-6 days would be required to reach similar mortality levels $(90 \%)$ at an air temperature of $15^{\circ} \mathrm{C}$ (Tables 23 ) for the population in the current study.

Our findings on the temperature implications, size classes, lethal temperatures and duration times provides valuable information on the effect of desiccation and air temperature on the mortality of $C$. fluminea. This is of auto-ecology interest and could be used by environmental managers for developing strategies (e.g., dewatering and water level management) for the control of this invasive species. These findings may also be useful as starting point for the development of specific protocols and tests (e.g. required number of days of air exposure for different temperature conditions) to avoid their spread via recreational boats and other submerged objects that may be transferred between waterbodies. When considering the potential wider indirect effects on aquatic ecosystems, proposed techniques to control the spread of $C$. fluminea (e.g., management of desiccation events, oxygen depletion or chemical treatments) should only be applied in heavily modified systems (i.e. with limited conservation interest) and after pilot studies. Artificial waterways, irrigation structures, pipes, cooling systems and power stations where $C$. fluminea establish populations would be suitable systems for the deployment of dewatering and desiccation measures as they could form part of routine management practices to prevent their wider dispersal into surrounding waterbodies.

Acknowledgements Thanks to Richard Harland (Laboratory Manager \& Safety Officer at Geography and Environment) and Mark Harrod (Technical Facilities Manager, School of Architecture, Building and Civil Engineering) for their support during the laboratory work. Thanks to Dr Susana Pallarés (Plymouth University) and Dr Alex Laini (University of Parma) for their helpful and useful suggestions on an early version of this manuscript. S. Guareschi was supported by a Royal Society-Newton International Fellowship at Loughborough University, UK (NIF\R1\180346). The authors wish to thank two anonymous for their helpful comments which improved the clarity of the manuscript. Symbols in SM_1 are provided courtesy of the Integration and Application Network, University of Maryland Center for Environmental Science (ian.umces.edu/symbols/).

\section{Compliance with ethical standards}

Conflict of interest The authors declare that they have no potential conflict of interest in relation to the study in this paper.
Open Access This article is licensed under a Creative Commons Attribution 4.0 International License, which permits use, sharing, adaptation, distribution and reproduction in any medium or format, as long as you give appropriate credit to the original author(s) and the source, provide a link to the Creative Commons licence, and indicate if changes were made. The images or other third party material in this article are included in the article's Creative Commons licence, unless indicated otherwise in a credit line to the material. If material is not included in the article's Creative Commons licence and your intended use is not permitted by statutory regulation or exceeds the permitted use, you will need to obtain permission directly from the copyright holder. To view a copy of this licence, visit http://creativecommons.org/licenses/by/4.0/.

\section{References}

Baker R, Clarke K, Howlett D (1999) The Asiatic clam Corbicula fluminea (Müller) new to the UK. The Ted Ellis Trust: Wheatfen Broad Nature Reserve 32:70-76

Bellard C, Cassey P, Blackburn TM (2016) Alien species as a driver of recent extinctions. Biol Lett 12:20150623

Bespalaya YV, Bolotov IN, Aksenova OV, Kondakov AV, Gofarov MY, Laenko TM, Sokolova SE, Shevchenko AR, Travina OV (2018) Aliens are moving to the Arctic frontiers: an integrative approach reveals selective expansion of androgenic hybrid Corbicula lineages towards the North of Russia. Biol Invas 20:2227-2243

Byrne RA, McMahon RF, Dietz TH (1988) Temperature and relative humidity effects on aerial exposure tolerance in the freshwater bivalve Corbicula fluminea. Biol Bull 175:253-260

Caffrey J, Evers SL, Millane M, Moran H (2011) Current status of Ireland's newest invasive species-the Asian clam Corbicula fluminea (Mueller 1774). Aquat Invas 6:291-299

Chiu MC, Leigh C, Mazor R, Cid N, Resh V (2017) Anthropogenic threats to intermittent rivers and ephemeral streams. In: Intermittent rivers and ephemeral streams (Eds: Datry, Bonada, Boulton). Academic Press, pp 433-454

Clavero M, Araujo R, Calzada J, Delibes M, Fernández N, Gutierrez-Exposito C, Revilla E, Román J (2012) The first invasive bivalve in African fresh waters: invasion portrait and management options. Aquat Conserv Mar Freshw Ecosys 22:277-280

Collas FP, Koopman KR, Hendriks AJ, van der Velde G, Verbrugge LN, Leuven RS (2014) Effects of desiccation on native and non-native molluscs in rivers. Freshw Biol 59:41-55

Coughlan NE, Walsh DA, Caffrey JM, Davis E, Lucy FE, Cuthbert RN, Dick JTA (2018) Cold as Ice: a novel eradication and control method for invasive Asian clam Corbicula fluminea using pelleted dry ice. Manag Biol Invas 9:463-474

Coughlan NE, Cuthbert RN, Dickey JW, Crane K, Caffrey JM, Lucy FE, Davis E, Dick JT (2019) Better biosecurity: 
spread-prevention of the invasive Asian clam Corbicula fluminea (Müller 1774). Manag Biol Invas 10:111-126

Crawley MJ (1993) GLM for ecologists. Blackwell Science Publications. Oxford, England

Crespo D, Dolbeth M, Leston S, Sousa R, Pardal MÂ (2015) Distribution of Corbicula fluminea (Müller 1774) in the invaded range: a geographic approach with notes on species traits variability. Biol Invas 17:2087-2101

Dunn OJ (1964) Multiple comparisons using rank sums. Technometrics 6:241-252

Elliott P, zu Ermgassen PSE (2008) The Asian clam (Corbicula fluminea) in the River Thames London England. Aquat Invas 3:54-60

Fenoglio S, Bonada N, Guareschi S, López-Rodríguez MJ, Millán A, Tierno de Figueroa JM (2016) Freshwater ecosystems and aquatic insects: a paradox in biological invasions. Biol Lett 12:20151075

Ferreira-Rodríguez N, Sousa R, Pardo I (2018) Negative effects of Corbicula fluminea over native freshwater mussels. Hydrobiologia 810:85-95

Folland CK, Hannaford J, Bloomfield JP, Kendon M, Svensson C, Marchant BP, Prior J, Wallace E (2015) Multi-annual droughts in the English Lowlands: a review of their characteristics and climate drivers in the winter half-year. Hydrol Earth Syst Sc 19:2353-2375

Gallardo B, Aldridge DC (2013) The 'dirty dozen': socio-economic factors amplify the invasion potential of 12 high-risk aquatic invasive species in Great Britain and Ireland. J Appl Ecol 50:757-766

Gallardo B, Aldridge DC (2018) Inter-basin water transfers and the expansion of aquatic invasive species. Water Res 143:282-291

Gama M, Crespo D, Dolbeth M, Anastácio PM (2017) Ensemble forecasting of Corbicula fluminea worldwide distribution: projections of the impact of climate change. Aquat Conserv Mar Freshw Ecosyst 27:675-684

Gomes C, Sousa R, Mendes T, Borges R, Vilares P, Vasconcelos V, Guilhermino L, Antunes A (2016) Low genetic diversity and high invasion success of Corbicula fluminea (Bivalvia Corbiculidae) (Müller 1774) in Portugal. PloS One 11:e0158108

Guo W, Kubec J, Veselý L, Hossain MS, Buřič M, McClain R, Kouba A (2019) High air humidity is sufficient for successful egg incubation and early post-embryonic development in the marbled crayfish (Procambarus virginalis). Freshw Biol 64:1603-1612

Hakenkamp CC, Ribblett SG, Palmer MA, Swan CM, Reid JW, Goodison MR (2001) The impact of an introduced bivalve (Corbicula fluminea) on the benthos of a sandy stream. Freshw Biol 46:491-501

Havel JE, Kovalenko KE, Thomaz SM, Amalfitano S, Kats LB (2015) Aquatic invasive species: challenges for the future. Hydrobiologia 750:147-170

Howells RG (1992) Annotated list of introduced non-native fishes mollusks crustaceans and aquatic plants in Texas waters Management data series 78. Texas Parks and Wildlife Dept, Austin Texas

Ilarri MI, Antunes C, Guilhermino L, Sousa R (2011) Massive mortality of the Asian clam Corbicula fluminea in a highly invaded area. Biol Invas 13:277-280
Johnson KI, Henager CH, Page TL, Hayes PF (1986) Engineering factors influencing Corbicula fouling in nuclear service water systems. Am Malacol Bull Spec Ed 2:47-52

Jou LJ, Liao CM (2006) A dynamic artificial clam (Corbicula fluminea) allows parsimony on-line measurement of waterborne metals. Environ Pollut 144:172-183

Karatayev AY, Padilla DK, Minchin D, Boltovskoy D, Burlakova LE (2007) Changes in global economies and trade: the potential spread of exotic freshwater bivalves. Biol Invas 9:161-180

Karatayev AY, Burlakova LE, Padilla DK, Mastitsky SE, Ole$\operatorname{nin} \mathrm{S}$ (2009) Invaders are not a random selection of species. Biol Invas 11:2009-2019

Laverty C, Nentwig W, Dick JT, Lucy FR (2015) Alien aquatics in Europe: assessing the relative environmental and socioeconomic impacts of invasive aquatic macroinvertebrates and other taxa. Manag Biol Invas 6:341-350

Lopes-Lima M, Sousa R, Geist J, Aldridge DC et al (2017) Conservation status of freshwater mussels in Europe: state of the art and future challenges. Biol Rev 92:572-607

McDowell WG, Benson AJ, Byers JE (2014) Climate controls the distribution of a widespread invasive species: implications for future range expansion. Freshw Biol 59:847-857

McDowell WG, McDowell WH, Byers JE (2017) Mass mortality of a dominant invasive species in response to an extreme climate event: implications for ecosystem function. Limnol Oceanogr 62:177-188

McMahon RF, Bogan AE (2001) Bivalves. In: Thorp JH, Covich AP (eds) Ecology and classification of North American freshwater invertebrates, 2nd edn. Academic Press, New York, pp 331-428

Montalto L, Ezcurra de Drago I (2003) Tolerance to desiccation of an invasive mussel Limnoperna fortunei (Dunker 1857) (Bivalvia Mytilidae) under experimental conditions. Hydrobiologia 498:161-167

Mouthon J (1981) Sur la présence en France et au Portugal de Corbicula (Bivalvia Corbiculidae) originaire d'Asie. Basteria 45:109-116

Müller O, Baur B (2011) Survival of the invasive clam Corbicula fluminea (Müller) in response to winter water temperature. Malacologia 53:367-371

Nakano D, Strayer DL (2014) Biofouling animals in fresh water: biology impacts and ecosystem engineering. Front Ecol Environ 12:167-175

Nentwig W, Bacher S, Kumschick S, Pyšek P, Vilà M (2018) More than "100 worst" alien species in Europe. Biol Invas 20:1611-1621

Ortmann C, Grieshaber MK (2003) Energy metabolism and valve closure behaviour in the Asian clam Corbicula fluminea. J Exp Biol 206:4167-4178

Pallarés S, Velasco J, Millán A, Bilton DT, Arribas P (2016) Aquatic insects dealing with dehydration: do desiccation resistance traits differ in species with contrasting habitat preferences? PeerJ 4:e2382

Paukstis GL, Tucker JK, Bronikowski AM, Janzen FJ (1999) Survivorship of aerially-exposed zebra mussels (Dreissena polymorpha) under laboratory conditions. J Freshw Ecol 14:511-517 
Peel MC, Finlayson BL, McMahon TA (2007) Updated world map of the Köppen-Geiger climate classification. Hydrol Earth Syst Sci 11:1633-1644

Prudhomme C, Giuntoli I, Robinson EL, Clark DB, Arnell NW, Dankers R, Fekete BM, Franssen W, Gerten D, Gosling SN, Hagemann S (2014) Hydrological droughts in the 21st century hotspots and uncertainties from a global multimodel ensemble experiment. Proc Natl Acad Sci USA 111:3262-3267

Rahiz M, New M (2013) 21st century drought scenarios for the UK. Water Resour Manag 27:1039-1061

Ricciardi A, Serroya R, Whoriskey FG (1995) Aerial exposure tolerance of zebra and quagga mussels (Bivalvia: dreissenidae): implications for overland dispersal. Can J Fish Aquat Sci 52:470-477

Rosa IC, Pereira JL, Gomes J, Saraiva PM, Gonçalves F, Costa R (2011) The Asian clam Corbicula fluminea in the European freshwater-dependent industry: a latent threat or a friendly enemy? Ecol Econ 70:1805-1813

Schaffelke B, Deane D (2005) Desiccation tolerance of the introduced marine green alga Codium fragile ssp tomentosoides clues for likely transport vectors? Biol Invas 7:577-587

Simberloff D, Martin JL, Genovesi P, Maris V, Wardle DA, Aronson J, Courchamp F, Galil B, García-Berthou E, Pascal M, Pyšek P, Sousa RO, Tabacchi E, Villa' M (2013) Impacts of biological invasions: what's what and the way forward. Trends Ecol Evol 28:58-66

Sousa RC, Antunes C, Guilhermino L (2008a) Ecology of the invasive Asian clam Corbicula fluminea (Müller 1774) in aquatic ecosystems: an overview. Annales de LimnologieInt J Limnol 44:85-94

Sousa R, Rufino M, Gaspar M, Antunes C, Guilhermino L (2008b) Abiotic impacts on spatial and temporal distribution of Corbicula fluminea (Müller 1774) in the River Minho Estuary Portugal. Aquat Conserv Mar Freshw Ecosys 18:98-110

Sousa R, Gutiérrez JL, Aldridge DC (2009) Non-indigenous invasive bivalves as ecosystem engineers. Biol Invas 11:2367-2385

Sousa R, Novais A, Costa R, Strayer DL (2014) Invasive bivalves in fresh waters: impacts from individuals to ecosystems and possible control strategies. Hydrobiologia 735:233-251

Strayer DL (2010) Alien species in fresh waters: ecological effects interactions with other stressors and prospects for the future. Freshw Biol 55:152-174
Tolonen KE, Picazo F, Vilmi A, Datry T, Stubbington R, Pařil P, Perez Rocha M, Heino J (2019) Parallels and contrasts between intermittently freezing and drying streams: from individual adaptations to biodiversity variation. Freshw Biol 64:1679-1691

Tucker JK, Theiling CH, Janzen FJ, Paukstis GL (1997) Sensitivity to aerial exposure: potential of systemwide drawdowns to manage zebra mussels in the Mississippi River. Regul Rivers: Res Manage 13:479-487

Venables WN, Ripley BD (2002) Modern Applied Statistics with S, 4th edn. Springer, New York. ISBN 0-387-95457-0

Verbrugge LN, Schipper AM, Huijbregts MA, Van der Velde G, Leuven RS (2012) Sensitivity of native and non-native mollusc species to changing river water temperature and salinity. Biol Invas 14:1187-1199

Weitere M, Vohmann A, Schulz N, Linn C, Dietrich D, Arndt H (2009) Linking environmental warming to the fitness of the invasive clam Corbicula fluminea. Glob Chang Biol 15:2838-2851

Werner S, Rothhaupt KO (2008) Mass mortality of the invasive bivalve Corbicula fluminea induced by a severe low-water event and associated low water temperatures. Hydrobiologia 613:143-150

Wittmann ME, Chandra S, Reuter JE, Schladow SG, Allen BC, Webb KJ (2012) The control of an invasive bivalve Corbicula fluminea using gas impermeable benthic barriers in a large natural lake. Environ Manage 6:1163-1173

Zamora-Marín JM, Zamora-López A, Sánchez-Pérez A, Torralva M, Oliva-Paterna FJ (2018) Establecimiento de la almeja asiática Corbicula fluminea (Müller 1774) en la cuenca del río Segura (SE Península Ibérica). Limnetica $37: 1-7$

Zar JH (2010) Biostatistical analysis, 5th edn. Old Tappan, Pearson, $\mathrm{p} 960$

Zieritz A (2016) GB non-native organism rapid risk assessment for Asian Clam (Corbicula fluminea) http://www. nonnativespeciesorg/factsheet/factsheetcfm?speciesId= 897. Accessed 29 Aug 2019

Zuur AF, Ieno EN, Walker NJ, Saveliev AA, Smith GM (2009) Mixed effects models and extensions in ecology with R. Springer, New York

Publisher's Note Springer Nature remains neutral with regard to jurisdictional claims in published maps and institutional affiliations. 